\title{
Teaching EFL Students Using Selected Media: Offline Video Taken From YouTube
}

\author{
Rohandi Yusuf \\ Universitas Lancang Kuning, Pekanbaru, Indonesia \\ yusufrohandi@unilak.ac.id
}

\author{
ARTICLE HISTORY \\ Received : 2019-06-30 \\ Revised : 2019-09-06 \\ Accepted :2020-03-24
}

\section{KEYWORDS}

Teaching Media Offline video YouTube EFL Students

\begin{abstract}
English is a foreign language that must be studied, there are four skills that students must master, namely writing, speaking, reading and pronunciation. The development of technology in the learning process of teachers is required to use media not only using books, markers, or other things that are not related to technology that will make teachers or students miss technological development. The current era of globalization is a lot of media or tools for teaching teachers, namely using smartphones, laptops, one of them is a website, application, social media such as Facebook, Instagram, Twitter, Line or other social media, and the last is YouTube. In this study we use YouTube offline video as a teaching media process. Using the media in the learning process and YouTube include new media or ways in the learning process and using YouTube definitely brings impact. Of course a positive impact for students or teachers in the learning process. This study will tell so much about the use of YouTube as a medium for teacher learning in learning English.
\end{abstract}

\section{Introduction}

English is interpreted as a foreign language in Indonesia. Today many people learn English as a need to communicate with strangers or according to their individual needs. Almost all English education becomes a foreign language that must be understood, and made into a tool of communication in everyday life. Education is a human effort in forming a personality that is in accordance with the values of life. in improving the quality of education is a very compulsory activity and requires a technique in realizing the business. In an education there is a professional teacher who is used to make education successful. An efficient and effective teaching and learning process is the goal of learning so that it must use media as a learning tool.

Teaching is seen as a system consisting of components that depend on each other, and organized the competencies that must be achieved by the students, the subject matter, methods and approaches to teaching, teaching media, learning resources, organizing classes, and assessment. There are several factors that cause the material was not accepted by the students. One is the concentration of students to the delivery of content. In addition, it should be also the teacher's role as manager of the class thus creating an atmosphere conducive classroom. The teacher's role may be helped by the media.

Media can be used by teachers as a companion in presenting the material in class. Media not only in the form of fast or intermediate can be directly used by teachers as props. Media can also be made known to the artificial media. Media artificial hone their creativity in learning. The use of media in teaching and learning is not an additional function, but it has its own function as a tool to achieve an effective teaching and learning situation.

In connection with the foregoing, the teaching of English is one of the tasks that are difficult for teachers. Learning English is more focused on students with language skills both orally and in writing. However, the problem often faced by teachers is on the issue of developing a media that is able to provide encouragement to the students to be motivated to be more active learning and practicing the language skills in everyday life. Expected benefits is theoretically able to contribute to the application of linguistic theory (Rahman, F., \& Amir, P., 2019; Wekke, I. S., Yandra, A., \& Hamuddin, B., 2017.

The practical benefits are as reference the development of more innovative learning model to both teachers and schools and promote creativity and the power of reason in the skills to develop a descriptive text for students. The core issues that must be resolved is to make students able to write and tell essay description by growing its imagination, when confronted with unfamiliar topics. For that, we need a learning innovation as an effort to improve the quality of learning to write or describe a picture.

Video offline from YouTube have the power to lure the attention and influence the attitudes and behavior of readers. The real characteristics of the image can shorten a long and complicated explanation via elements of the displayed image so that it becomes simple and easy to understand. Therefore, media images can not be ignored or underestimated. The media can make a positive contribution to children 
through nature, namely making children feel happy and grow a child's imagination.

Multimedia Teaching enrich the content of classroom teaching and make the best possible time and to break the pattern of teaching "teachercentered" and fundamentally improve classroom efficiency. Due to a large class is difficult for students to have communication to speak. Traditional teaching model especially emphasizes the teacher's instructions, and information is limited because of the traditional classroom. In contrast, multimedia technology beyond space and time, creating a more vibrant environment, visual and authentic to learn English, to stimulate student initiative and save class time while increasing class information, it gets the students who dared to speak English.

Furthermore, the expected benefits is theoretically able to contribute to the application of linguistic theory, especially in the areas of teaching and learning of English among learners through video offline from YouTube media development in writing descriptive text. The practical benefits are as reference the development of more innovative learning model to both teachers and schools and promote creativity and the power of reason in writing skills for learners

(Munadi, 2012) Media is anything that can convey and channel messages from a planned source so as to create a conducive learning environment and can carry out the learning process efficiently and effectively. Learning is a process of communication between students, educators and teaching materials. Communication will not run without the help of means of delivering messages or media. If a teacher does not use any media, there will be no interesting learning process.

Students need something new in their learning process in improving English skills. the learning process is a matter of their motivation. If they are motivated and interested in learning English, they will be able to master the language easily. And so much media can be done by teachers in learning activities so that they can facilitate students and make students more interested in learning materials.

Media can be used anytime and anywhere. For example, through images, video, text can support material sharing from teacher to student. Successful education can be measured from the results or results of the teaching and learning process itself. There are several functions of learning media more than two things, namely analysis of functions based on the media and its users. This is explained by (Munadi, 2012: 36) that the analysis of functions based on media has three functions of learning media, namely:

1) Learning media function as learning resources;

2) Semantic functions;

3) And manipulative functions.
While the analysis of functions based on users (students), namely:

1) Psychological functions;

2) Socio-cultural functions. There are several media that can be used in teaching media, one of which is YouTube media.

YouTube includes teaching media that teachers can do in learning in the classroom. YouTube is indeed not only an educational video site, but in its development youtube launched a special service for education (www.youtube.com/ edu) in 2009. This service immediately received a positive response from users. YouTube can be a learning resource and learning media that can meet the needs of students and teachers, YouTube can increase interest and support student learning styles. YouTube also offers learning experiences with new technologies that will be useful when they graduate (Burke, Snyder, \& Rager, 2009). In addition, YouTube also provides hundreds of thousands of videos with a variety of topics that can be obtained for classroom learning. YouTube will also be a very free video library for learners who will encourage them to become independent learners.

YouTube as the most popular video variety site today and the emergence of YouTube as a medium for teachers and easy to do for a teacher to learn how to teach well and provide opportunities and challenges for teaching English. From the explanation of media on YouTube can play an important role in helping students understand their English lessons, improve their performance, and advance their understanding of English.

The purpose of utilizing YouTube as a learning media is to create learning conditions that are interesting, fun and interactive. Learning videos on YouTube can be used for interactive learning in the classroom, both for students and the teacher itself through presentations online and offline. The use of YouTube as a learning media can be used at any time without being limited by space and time with computer terms or presentation media connected to the internet.

YouTube has several advantages as learning media, namely: YouTube is the most poluper site in the internet today that is capable of education / education to be attractive; YouTube media is easy to use and can be followed by all groups including students and teachers; youtube provides information about the development of the science of education, technology, culture; youtube facilitates us to discuss or do questions and answers; YouTube is free for all people.

And in using YouTube media as a learning media there are 2 Video Offline and Online. In this article I use Video Offline besides being able to simplify the learning process using Oflline video, it will not 
interfere with the learning process such as disruption of internet networks, capacity of packages to open the internet and so on. In addition, in utilizing YouTube as a learning medium, a teacher must know in detail about how to search or search for learning videos on YouTube to increase students 'or teachers' knowledge. Seeing this condition, the authors write the use of Youtube as a learning media.

\section{Methods}

This article is based on English language learning activities at Junior High School by utilizing YouTube. Almost all students are all generations of the internet. Offline media video originating from YouTube is used to obtain facts about learning material about the material to be taught and for learning English and to provide opinions on the benefits of the learning process using media video offline from YouTube. In addition, it can also be used to disclose, the use of video media offline from YouTube.

The media used in the learning process is offline video that has been downloaded on the youtube application by the teacher so that there is no disruption in the learning process such as the network, the lights turn off, the wi-fi connection is not good so the learning process is interrupted and not be effective.

And in discussing the material students can develop ideas, students can do something new, improve student creativity in thinking, and many other things that can be obtained in the learning process using YouTube media with offline video.

\section{Result}

The use of YouTube as a medium for learning English is actually very important, because through YouTube students can learn or hear native speakers speak English directly. By looking at it, watching will certainly give birth to a strong self-confidence that the language and pronunciation that is seen and heard is right, so that when practicing the student will be very confident and not shy about what he wants to say. The more often someone hears an English learning video from YouTube, the more fluent the person will be. YouTube provides a variety of important information in the form of videos that can be accessed by anyone. This facility can be used for educational purposes such as the introduction of Colors, months, days, counts, greetings, objects that are around us and many other facilities.

Although the facilities are very large, not everyone wants to use them for education. This research was conducted by utilizing YouTube for the world of education, one of which is learning English. Some students express their opinions that videos from YouTube can overcome boredom. In addition they also stated that the use of videos from YouTube has increased their interest in learning. students also stated that using videos from YouTube is more interesting than just reading learning resources from books or listening to lectures only. Some students also expressed the importance of choosing videos that have good sound and picture quality.

The next step is to introduce a variety of simple methods for downloading English chasing materials. The first way is to introduce YouTube and the second is to download video according to the material. In this session participants were not burdened with complicated material and theory. and the teacher immediately tries repeatedly how to learn good and desired English.

In the beginning, the understanding of the teacher or students towards the YouTube facility was not maximized, they did not fully understand that YouTube provides various information that is very useful for teaching. This is caused by several factors, among others, the teacher focuses more on the existing curriculum and does not fully want the new teaching media.The second factor is the still lack of technological and information facilities (lack of wifi, infocus and network facilities that are difficult), after teachers and students are given understanding and tried to apply it turns out that YouTube learning media is one way that can be used by the teacher as a medium to deliver material when learning process. And YouTube media is very making students interested and more enthusiastic in the learning process things that make the attraction higher.

This is in line with what was revealed by Edgar Dale, watching YouTube is better than just reading or listening. In addition, YouTube can also be used for almost all topics, learning models, and every domain: cognitive, affective, and psychomotor. In the cognitive domain, students can observe dramatic recreation of past historical events and actual recordings of current events, because the color, sound and motion elements here can make the classroom atmosphere feel more alive.

In addition, by viewing YouTube, after or before reading, it can strengthen students' understanding of teaching material.In the affective domain, YouTube can strengthen students to feel the emotional elements and attitude of effective learning. In the psychomotor realm, YouTube has the advantage of showing how things work, learning videos that record motoric / motion activities can provide opportunities for students to observe and reevaluate these activities.

YouTube is rich in information to be informed in the learning process because learning can reach students directly. In addition, YouTube adds a new atmosphere to learning, students not only see images of printed teaching materials and sounds from audio programs, but on YouTube, students can get both, namely moving images and accompanying sounds. Utilization of youtube can stimulate creativity, interest and motivation of teachers, besides that 
through youtube, English language skills, preparation of teaching materials, selection of materials, ways of delivering teachers progress, which initially only examples and copied from YouTube into material, new material full of ideas in their own style. YouTube also indirectly increases the interest in reading among them, in terms of finding ideas and material.

\section{Discussion}

In this Article choose Procedure Text as material. It was chosen based on the consideration that the material was based on competency standards. Words are chosen in the hope that students can remember their prior knowledge of the topic so they can imagine it. An example is "Procedure Text". The material itself is prepared by adjusting the level of students in English.Researchers realize that every media must have strengths and weaknesses. For YouTube Video Offline as a learning media, the strength found by researchers in learning can be explained as follows:

1) Media that really involves students to remember a few words through video. What students see

2) Media can help students to imagine meaning words and get a better understanding easily.

3) Students are eager to use words from the media to apply them in their work.

As Kusriani (2008) said that the teaching and learning process with YouTube media is more fun and educational. He also said that by using YouTube media in class, it can stimulate students' brains to be more creative. YouTube media using colorful and funny Video Offline attracts students, thus eliminating the boredom of students in the class. Video media YouTube is a teaching and learning media that can be seen and imagined by students. This helps students to express their ideas after seeing video. Based on what was seen, during the learning process using offline video on YouTube that the class situation was still alive. Student participation is also high and gives good attention to the lesson. The students even participate actively when the teacher asks them to make procedure text. They must know how to make a text procedure, and the steps that must be taken to Procedure Text. After that, YouTube Media also helps to make students better at telling procedure text Like how students can develop their ideas well. And knowing the purpose of the procedure text tells the material and the steps with good and clear grammar. For teachers, this YouTube media can help teachers explain material easily.

Teachers can use Video Offline media from YouTube as an easy way to increase students' knowledge of Procedure Text mainly related to their writing procedures, Grammar, pronunciation. Regarding the discussion above, it can be concluded that the use of video media offline from YouTube is effective for students. Therefore, I conclude that teaching Procedure Text using offline video media is very influential in student learning on the material.

\section{Conclusion}

The use of YouTube in the English language class is very helpful material for the learning process. not only comes from books and YouTube helps the internet generation who are familiar with various sources of information better understand learning material. Learning English by using video offline comes from youtube, it's very fun because the YouTube facility is very various and can be chosen according to the wishes of use.

English teaching materials are also available and can be accessed by anyone, so that they can be used for teaching English and other subjects. Using YouTube media can make teachers and students easier for them to get ideas and increase teacher creativity in the teaching and learning process in the classroom, and students when listening to the teacher's explanation in the classroom. This activity can be continued in other schools because it provides benefits not only to the teacher but to students.

By using YouTube, learning becomes more interesting and increases the positive stimulation of students to learn English. Besides that YouTube has several advantages as a learning media that is Potential, Practical, Informative, Interactive and Economical.

When using YouTube media, video offline to teach, the teacher must be prepared for any situation that might occur during the learning process. For example, when a teacher explains material a student might talk. So, the teacher must handle it well. Thus, through the application of the YouTube media, video offline it can provide a positive influence on students and the continuity of the teaching-learning process in the classroom

Teaching Procedure Text by using YouTube media, video offline, there are very ordinary differences in the learning process. It means that the learning process between teachers and students is better than before the media was done. Offline media from YouTube helps students to get their ideas easily.

Their participation is also high and good attention during the teaching and learning process. The application of this media greatly helps students to be more enthusiastic in learning, they do not feel burdened to learn and they are interested in participating in the teaching and learning process. The opinions of students on the use of video in the class get a positive response. Introducing YouTube in English classes succeeded in increasing student interest and interest so that this material was no longer considered a difficult and tedious learning.

\section{References}

Anderson, R. H. (1994). Penelitian dan Pengembangan Media untuk Pembelajaran. Edisi I, Cet. I 
Berk, R. A. (2009). Multimedia teaching with video clips: TV, movies, YouTube, and mtvU in the college classroom. International Journal of Technology in Teaching \& Learning, 5(1).

Bonk, C. J. (2011). YouTube anchors and enders: The use of shared online video content as a macrocontext for learning. Asia-Pacific Collaborative Education Journal, 7 (1). Retrieved from http://www. acecjournal. org/2009/Journal_Data/Vol7No1/201103.pdf. In in delivery?, Public Purpose Magazine (from the American Association of State Colleges and Universities). Retrieved June 6, 2013, from http://www. aascu. org/WorkArea/DownloadAsset. aspx $? \mathrm{id}=5570$

Burke, S. C., Snyder, S., \& Rager, R. C. (2009). An assessment of faculty usage of YouTube as a teaching resource. Internet Journal of Allied Health Sciences and Practice, 7(1), 8.

Catropa, D.(2013, February 24). Big (MOOC) data. Inside Higher.

DeWitt, D., Alias, N., Siraj, S., Yaakub, M. Y., Ayob, J., \& Ishak, R. (2013). The potential of Youtube for teaching and learning in the performing arts. Procedia-Social and Behavioral Sciences, 103, 1118-1126.

Faiqah, F., Nadjib, M., \& Amir, A. S. (2017). Youtube Sebagai Sarana Komunikasi Bagi Komunitas Makassarvidgram. KAREBA: Jurnal Ilmu Komunikasi, 5(2), 259-272.

Hajar, I. (2019). Youtube Sebagai Sarana Komunikasi Dakwah Di Kota Makassar (Analisis Sosial Media). Jurnal Al-Khitabah, 4(2).

Rahman, F., \& Amir, P. (2019). Trends in Reading Literary Fiction in Print and Cyber Media by Undergraduate Students of Hasanuddin University. International Journal of Education and Practice, 7(2), 66-77.

Wekke, I. S., Yandra, A., \& Hamuddin, B. (2017, December). Learning Strategy in Class Management: A Reflection from Manado Case. In IOP Conference Series: Earth and Environmental Science (Vol. 97, No. 1, p. 012053). IOP Publishing. 